\title{
The Late Antique glass furnaces in the Hambach Forest were working glass - not making it
}

Th. Rehren ${ }^{1,2}$ and M. Brüggler ${ }^{3}$

1 Science and Technology in Archaeology and Culture, The Cyprus Institute, Nicosia, Cyprus; th.rehren@cyi.ac.cy; 003579963 6266. ORCID 0000-0002-9169-1198

2 UCL Institute of Archaeology, Gordon Square 31-34, London WC1H OPY, UK

3 LVR - State Service for Archaeological Heritage in the Rhineland, Dep. Xanten, Augustusring 3, 46509 Xanten, Germany

\section{Abstract}

The cluster of Late Antique glass furnaces in the Hambach Forest in the Rhineland, western Germany, has been advocated by K. H. Wedepohl and G. Hartmann in their influential papers as a potential location for primary glassmaking. Here, we re-evaluate and expand the original chemical data and assumptions underpinning this controversial interpretation, and present an alternative explanation for the compositional pattern observed among the glass finds from the site and its wider environment. Glass matching very closely the two main chemical compositions as seen in the Rhineland has recently been reported from numerous $4^{\text {th }}$ to $5^{\text {th }}$ century sites in Southern France, Britain, Italy, the Balkans and Egypt, with the same pattern of minor amounts of colorant elements such as copper, tin, lead and antimony, as contamination due to the inclusion of recycled cullet into the batch. The high content in iron and related elements, previously seen as a unique characteristic of the Hambach Forest glass finds, is now recognised as a common feature of these established super-regional compositional glass groups. We identify the majority of analysed finds to consist of HIMT glass, followed by a significant number of série 3.2 glass sensu Foy et al. (2003), while only one sample matches glass of the Levantine composition. This sees the furnaces of the Hambach Forest, and the finished vessels excavated in the wider region, fully integrated in the two-tier Late Antique glass industry, where a few eastern Mediterranean mega-producers were supplying their raw glass across the Empire to be re-melted and worked locally into artefacts, including at the cluster of glass furnaces in the Hambach Forest.

Keywords: Late Antique glass; chemical analysis; Roman archaeology

\section{Introduction}

Among scholars of Roman glass technology, the western German region of the Hambach Forest is well-known for its suite of glass furnaces, first identified in the 1930s (see Gaitzsch et al. 2000: 83-5) and expertly excavated in development-led rescue-excavations since 1975 first by M. Rech and then by W. Gaitzsch, ahead of the complete destruction of the area in the course of the ongoing lignite open-cast mining. At least 40 separate glass furnaces were identified across 10 different sites (Fig. 1), operating from the first half of the $4^{\text {th }}$ to the mid- $5^{\text {th }}$ century AD (Brüggler 2009, Brüggler forthcoming, Wagner et al. in print), that is over a period of more than a century producing a wide range of objects. They supplied the wider regional Late Antique landscape of forts and settlements along the Lower Rhine and even feeding into the major urban market of Cologne, among others. Famous among the vessels produced are the 'ECVA' barrel jugs, found from Mainz to Krefeld along 
the left (Roman) bank of the Rhine, whose production can be traced to the glass furnaces in the Hambach Forest (Follmann-Schulz in Gaitzsch et al. 2000; Follmann-Schulz 2015). Over more than a century of archaeological work, countless Late Antique glass vessels and fragments have been excavated in the Lower Rhineland, both from cemeteries and from urban and other 'living' contexts, consistent with the presence of a significant cluster of glass furnaces near-by. Understanding the role and extent of these workshops therefore is of major significance for the archaeology of the northern Roman provinces.
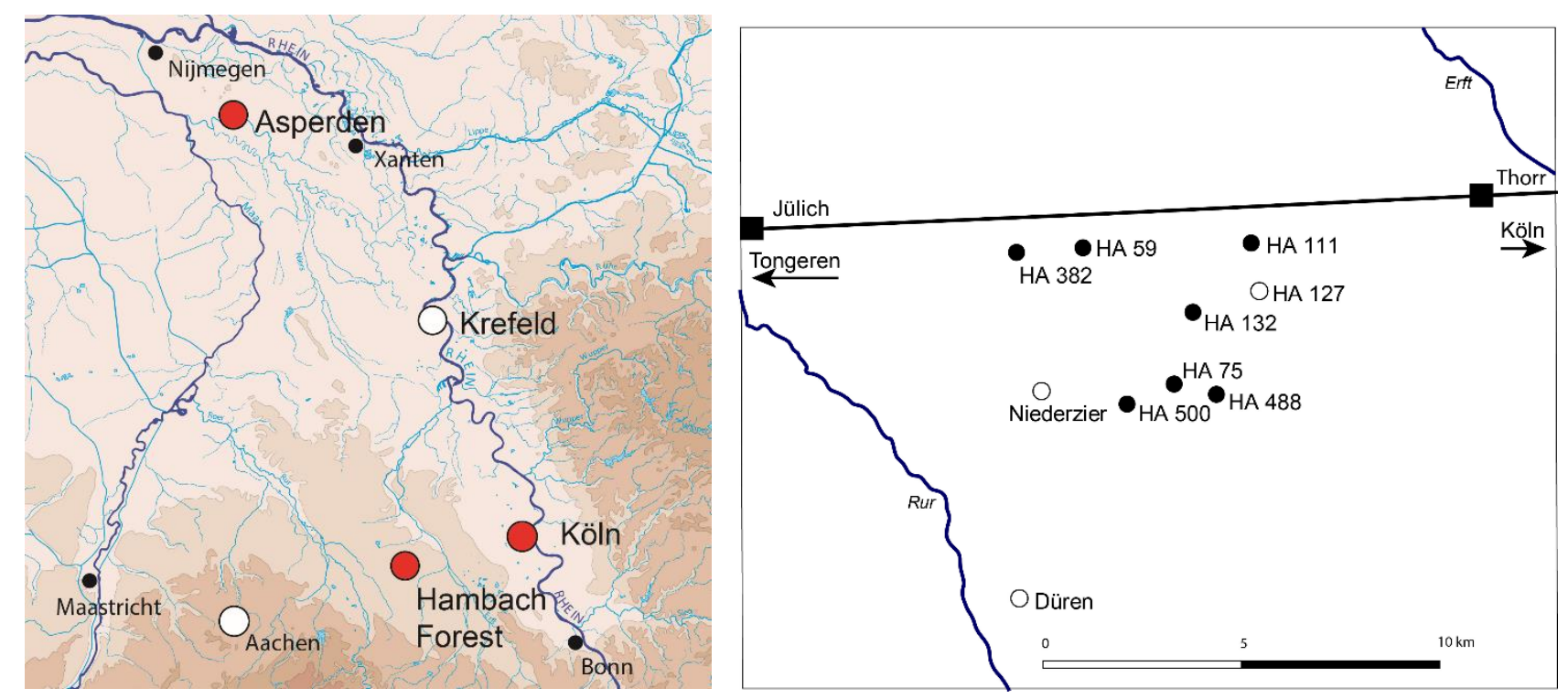

Fig. 1: Late Antique glass factories (red dots: furnaces as evidence; white dots: glass crucibles as evidence for glass-working) in the Rhineland (left) and (right) in the Hambach Forest south of the Roman road from Köln (Cologne) to Tongeren near Maastricht (black dots: sites with furnaces as evidence, white dots: glass-working surmised from finds).

This significance has been further heightened by a substantive body of analytical work, in which K.H. Wedepohl and G. Hartmann analysed numerous Late Antique and early medieval glass samples from northwest Germany (e.g. Wedepohl 1997; Wedepohl et al. 1997; Wedepohl \& Baumann 2000; Wedepohl 2003; see also Rehren \& Kronz 2017). One of their main studies concerned the glass finds from the furnaces of the Hambach Forest and related Late Antique cemeteries (Wedepohl \& Hartmann 2000 in Gaitzsch et al. 2000).

\subsection{Primary production or secondary working?}

The Hambach Forest site is at the centre of a drawn-out debate regarding primary glassmaking in the northern Roman provinces. Some time ago, Jackson and co-workers (Jackson et al. 1998; 2003; Cool et al. 1999; see also Price 2003: 88-9) published several papers on possible very small scaleexperimentation in glassmaking based on semi-fused materials from Roman York. At the same time, Wedepohl and Hartmann were working on the Hambach Forest material. In their main publication (Wedepohl and Hartmann 2000), and a number of subsequent papers, (e.g. Wedepohl et al. 2003), they argued for a local primary glass production in the Hambach Forest, proposing that it was based on the sand deposits from the near-by river Rur, imported natron from Egypt and sea shells from the North Sea coast. More recently, Degryse and co-workers have argued forcefully for the possibility of 
primary glassmaking in the western Roman empire, based primarily on detailed isotopic and trace element studies of Mediterranean beach sand deposits (e.g. Brems et al. 2012; Degryse (ed.) 2014 and papers therein; Degryse 2017) and their comparison to Hellenistic and Roman glass, although no archaeological evidence for such production has come to light yet.

The assumption of a local raw glass production in the Hambach Forest is purely based on archaeometric analyses of glass finds, despite the richness of workshop remains from the region. There is no conclusive excavated evidence that supports primary glassmaking (cf. for a detailed discussion of this point: Brüggler 2009: 86-90). However, the general lack of confirmed glassmaking sites outside the Levant leads to the question of what kind of evidence would indicate raw glass melting? Taking the Levantine evidence as a guide (e.g., Gorin-Rosen 2000), the remains of large tank-furnaces which can melt large quantities of raw materials should be present. These are lacking in the eight excavated sites in the Hambach Forest, apart from one dubious square structure on the site HA 111 made of layered mortar and plaster that is interpreted by the excavator as a tank furnace (Gaitzsch et al. 2000: 105). Since it shows no traces of firing and furthermore is made of unsuitable materials, this interpretation is questionable. Even though, tank furnaces in themselves are no proof of raw glass production and small tank furnaces are now known from several glass working sites, among others in London where tank furnaces dominate the evidence (Keily \& Shepherd 2005; Shepherd 2015: 34), and Bonn and Sarmizegetusa where they can probably be brought in connection with the production of window panes (Băeştean \& Höpken 2009, 223). It can, however, be argued that it is possible to fuse sand, soda and lime into raw glass also in crucibles in a working furnace otherwise used for shaping glass, as proposed by Jackson et al. $(1998 ; 2003)$ for Roman York, and was shown in experimental glass working done in the Archaeological Park Roman Villa at Borg (F. Wiesenberg pers. comm.). Also, the furnaces at the site HA 132 were in fact fired to temperatures were raw glass production would have been possible (Brüggler \& Daszkiewicz 2004). Raw glass production in a glass-working furnace, however, would not leave specific traces. Other traces of a possible raw glass production could be pits or vessels for storing the raw materials sand, soda and lime resp. sea-shells. No such traces have been found and would indeed hardly be recognisable.

Despite the substantial archaeological evidence of primary tank furnaces in the Levant and northern Egypt, very few archaeometric studies of primary glassmaking remains based on mineral natron have been published so far, apart from a paper on furnace remains from the Wadi Natrun (Saleh et al. 1972) and one on finds of semi-finished glass from Hellenistic Rhodes (Rehren et al. 2005). This is to a large extent due to the particularity of glassmaking leaving very little waste, and restricts the discussion very much to the analysis of the finished glass, emphasising the importance of (geo)chemical analyses and their interpretation.

\subsection{Reception of previous work}

Within the German-speaking archaeological community, Wedepohl's interpretation is widely accepted (cf. Brüggler 2009: 86-90; Follmann-Schulz 2015: 25; Grünewald \& Hartmann 2015: 156; I. Freestone pers. comm. August 2018: "virtually every German archaeologist I talk to believes in primary production in the Hambach Forest"), and has made its way also into the international literature (e.g. Wilson et al. 2012: 375; Price 2005: footnote 1). Others have seen this proposed primary production of natron-based glass north of the Alps more critical (Nenna 2006: 118-119; Brüggler \& Rehren 2014: 170); Freestone et al. (2009: 44) in particular pointed out the chemical and isotopic similarity of the Hambach Forest glass to HIMT glass, and postulated their common, 
potentially Egyptian origin. However, in view of the more recent work by Brems and Degryse (see above) and the limitations in particular of the isotopic data ${ }^{1}$, a renewed detailed critical assessment of the chemical data from the Hambach Forest seemed warranted.

In this paper, we present new analytical work on selected samples from several Hambach Forest sites, including samples previously analysed by Wedepohl and Hartmann (2000), in an attempt first to determine the consistency and comparability of their data, obtained by WDS-XRF analysis, with the growing corpus of Late Antique glass data generated more recently by LA-ICP-MS (e.g. Gratuze 2013). Based on this, we reconsider the interpretation of this data in view of recent literature and our developing understanding of the organisation of the Late Antique and early Byzantine glass industry more widely.

\section{Sites, samples and methods used}

The Hambach Forest region was home to at least ten sites on which glass was worked. Two of the sites consist of surface-finds only (Düren, Niederzier), at one of the 8 excavated sites (HA 127) glass working is evident due to specific finds of working waste, while on the remaining seven sites at least 40 individual furnaces were excavated (see Fig. 1). It is not the aim of this paper to detail the excavated evidence, since this has already been published elsewhere (Gaitzsch et al. 2000, FollmannSchulz 2015, Brüggler forthcoming, Wagner et al. in print). Some of the sites have been studied in detail (HA 132: Brüggler 2009, HA 59: Hallmann-Preuß 2002/2003, HA 382: Wagner in preparation; HA 500: Heege 1997), and a brief summary may suffice here. The sites were situated in abandoned villae rusticae of the High Empire. Apart from workshop remains such as shelters, pits, wells etc. some sites also show settlement traces. At HA 132 the former main building of the villa rustica was restructured by the glass-workers and probably used as dwelling (cf. Brüggler 2009 for details). In addition to the workshop and settlement remains, graves that have to be seen in context with the glass working were found in HA 132 (38 graves), HA 500 (1 grave) and HA 382 (3 graves). Here, we focus on glass finds from the eight excavated workshop sites (Table 1).

Table 1: Synthesis of Hambach Forest (HaFo) sites from which we analysed glass finds (obj = finished objects; $w w=$ working waste; $c r=$ crucible glass), and their date range. Each site consists of an abandoned villa rustica reused for glass working; some have associated graves with glass vessels. See Table 2 (Sample Catalogue) for details.

\begin{tabular}{|l|l|l|l|l|}
\hline Site & Finds analysed & Proposed date c AD & Based on & References \\
\hline HaFo 59 & 0 obj, $2 \mathrm{ww}, 1 \mathrm{cr}$ & $1^{\text {st }}$ half $4^{\text {th }}-$ mid-5 $^{\text {th }}$ & $\begin{array}{l}\text { Overall site } \\
\text { chronology }\end{array}$ & Gaitzsch et al. 2000 \\
\hline HaFo 75 & 2 obj, $3 \mathrm{ww}, 1 \mathrm{cr}$ & Early to mid-4 & Stratigraphy & $\begin{array}{l}\text { Gaitzsch et al. 2000; } \\
\text { Brüggler 2009 }\end{array}$ \\
\hline HaFo 111 & 2 obj, $5 \mathrm{ww}, 2 \mathrm{cr}$ & $1^{\text {st }}$ half $4^{\text {th }}-$ mid-5 $^{\text {th }}$ & $\begin{array}{l}\text { Overall site } \\
\text { chronology }\end{array}$ & Gaitzsch et al. 2000 \\
\hline HaFo 127 & 0 obj, $7 \mathrm{ww}, 1 \mathrm{cr}$ & $1^{\text {st }}$ half $4^{\text {th }}-$ mid-5 $^{\text {th }}$ & $\begin{array}{l}\text { Overall site } \\
\text { chronology }\end{array}$ & Gaitzsch et al. 2000 \\
\hline
\end{tabular}

\footnotetext{
${ }^{1}$ A full discussion of the isotopic evidence is outside the remit of this paper. Suffice to say that the main isotope ratios used in ancient glass research concern $\mathrm{Sr}, \mathrm{Nd}$ and $\mathrm{Pb}$. Most of the strontium in Roman glass is derived from the lime source, typically recent sea shells which have the same ${ }^{87} \mathrm{Sr} /{ }^{86} \mathrm{Sr}$ ratio regardless of geographic origin; neodymium is thought to represent the silica source, but $\varepsilon N d$ values are only a very broad measure of origin. Lead isotope ratios, finally, are affected by added colorants and recycling, preventing their easy use for provenance determination.
} 


\begin{tabular}{|l|l|l|l|l|}
\hline HaFo 132 & $10 \mathrm{obj}, 2 \mathrm{ww}, 0 \mathrm{cr}$ & See catalogue & Morpho-typology & Brüggler 2009 \\
\hline HaFo 382 & 5 obj, $4 \mathrm{ww}, 0 \mathrm{cr}$ & $\begin{array}{l}2^{\text {nd }} \text { half } 4^{\text {th }}-\text { early } 5^{\text {th }} \\
\text { (see catalogue) }\end{array}$ & $\begin{array}{l}\text { Context \& morpho- } \\
\text { typology }\end{array}$ & $\begin{array}{l}\text { Gaitzsch et al. 2000; } \\
\text { Wagner 2004 }\end{array}$ \\
\hline HaFo 488 & 0 obj, $4 \mathrm{ww}, 0 \mathrm{cr}$ & $1^{\text {st }}$ half $4^{\text {th }}-$ mid-5 $^{\text {th }}$ & $\begin{array}{l}\text { Overall site } \\
\text { chronology }\end{array}$ & Gaitzsch et al. 2007 \\
\hline HaFo 500 & 1 obj, $3 \mathrm{ww}, 1 \mathrm{cr}$ & See catalogue & $\begin{array}{l}\text { Coin hoard, dendro- } \\
\text { dated well }\end{array}$ & Gaitzsch et al. 2000 \\
\hline
\end{tabular}

In order to cover the full range of glass artefacts across the Hambach Forest sites, we selected fragments of finished objects, working waste such as glass chunks, moils, trails and drips of glass, and glass attached to pots or crucibles. Our selection included 21 samples from among the fragments analysed previously by Wedepohl and Hartmann, supplemented by additional samples from two sites excavated more recently (HA 127 and HA 488), aiming at further broadening the already-substantial data base of analysed glass finds from the region. All in all, data for 56 samples is reported here. Several samples were visually heterogeneous and therefore analysed at multiple positions, resulting in a total of 62 analyses. Two intentionally coloured glass fragments were also analysed, one dark blue sherd and one black bracelet; the data is given in the table but not further discussed here. Several more samples were analysed, particularly from glass crucibles in order to determine the type of glass worked. These are also reported but not further discussed here as the glass was found to be severely contaminated by high levels of alumina (reaching from 3 to $15 \mathrm{wt} \%$ ) and iron oxide (from 1.5 to $9 \mathrm{wt} \%$ ), making a meaningful discussion of the data in the context of our research impossible.

Table 2: Catalogue of samples

When selecting the samples, we made sure to include samples from all the excavated sites. The number of samples differs from site to site due to the availability of appropriate material. The stratified contexts are listed in detail in Table 2. We analysed three samples from HA 59, six from HA 75, nine from HA 111, eight from HA 127, 12 from HA 132, nine from HA 382, four from HA 488, and five from HA 500. Working waste from the furnaces themselves included samples HaFo 111.8, HaFo 132.10 and HaFo 132.13. Other sampled finds stem from the vicinity of the furnaces (HaFo 75.2, HaFo 75.3, HaFo 75.4), and some from contexts belonging to the workshops (HaFo 382.3, HaFo 382.4 and HaFo 382.6 were found in a large pit containing much waste from glass production; the samples HaFo 59.1, HaFo 59.2 and HaFo 59.3 are from the infill of a pit or small pond). 18 samples were taken from vessels that were deposited as grave-goods on the sites HA 132 and HA 382 (HaFo 132.18, HaFo 132.11, HaFo 132.12, HaFo 132.14, HaFo 382.1, HaFo 382.2, HaFo 382.5, HaFo 382.7-10; cf. Gaitzsch et al. 2000: 182-210 and Brüggler 2009: 418-462 for a full catalogue of the grave inventories). Since only some of the excavated sites have been investigated in post-excavation studies (cf. above and Wagner et al. (in print) for details), not all the information for the contexts from which the samples stem can be given at this stage prior to their detailed examination. For the working waste we included different categories of finds such as trails, moils, raw glass chunks, and chunks of glass with adhering burnt loam. Glass from the residual contents of crucibles is presented as a separate category, as it most convincingly represents evidence for glass worked on site; while moils and other working waste also points at local glass working, such finds could have been procured at least theoretically from workshops elsewhere. 
We also considered chronological aspects to check whether a development in the use of the raw material within the production period can be determined. Since production debris itself can hardly be dated, the date was taken by either context or object-type - the latter only in the case of vessels. The dates are determined by morpho-typological analysis and are accordingly only rough. The analysed samples cover dates ranging from the $1^{\text {st }}$ half of the $4^{\text {th }}$ century to the middle of the $5^{\text {th }}$ century.

The samples were analysed by B. Gratuze at the LA-ICPMS instrument of the UMR IRAMAT in Orleans, France, using a standard protocol previously published (Gratuze 2013) and monitored against a number of reference glasses for which compositions are assumed to be known. LA-ICPMS routinely determines the concentration of more than 50 different elements in the glass. We report here major and minor elements as weight percent oxides with oxygen determined based on stoichiometry, while trace elements are reported as elements in microgram per gram.

\section{Results}

The comparison of our analysed values for Corning A and B glasses with published data demonstrates a close correspondence between the two, with typically less than $5 \%$ difference between the published values and the average of 14 individual measurements taken alongside the samples from the Hambach Forrest (Table 3). A higher difference was observed for calcium oxide in Corning A compared to the published value (Adlington 2017); according to Gratuze (pers. comm.) this discrepancy is not seen in his analyses of calcium oxide in other reference (e.g., Corning B) and certified reference glasses, and is likely an artefact of this particular Corning A block. Higher discrepancies, as seen for instance for low concentrations of phosphate (Corning A) or titania and strontium (Corning B), are probably at least in part due to rounding effects in the published data in Adlington (2017). Table 4 reports the new LA-ICPMS data sorted by artefact type (Finished objects; Working waste; and Glass inside melting pots); each section is further sorted by compositional group. The table also provides data on two intentionally coloured objects and on 14 heavily contaminated glass samples from inside melting pots or otherwise adhering to burnt loam; these analyses are not further discussed in the text below, but are provided for completeness and comparison with other such contaminated glass elsewhere.

Table 3: Juxtaposition of the compositional results obtained for Corning $A$ and B measured alongside the unknown (HaFo) samples and the recommended values from Adlington (2017). The measured values given here are the average of 14 individual measurements; marked in brown are those where this average differs more than 5\% (relative) from the published value.

\subsection{Comparison of WDS-XRF and LA-ICPMS data}

The existing corpus of WDS-XRF analyses of glass samples from the Hambach Forest done during the late 1990s has no corresponding analyses of known reference glasses reported with them. Even though the quality of data from the geochemical laboratory of the University of Göttingen is not in doubt we decided to first determine the degree of consistency between the results obtained by our new analyses and those published in 2000 by re-analysing several fragments from the earlier series. As expected, for most elements this showed a close correspondence of the two datasets (Figs. 2a, b). 

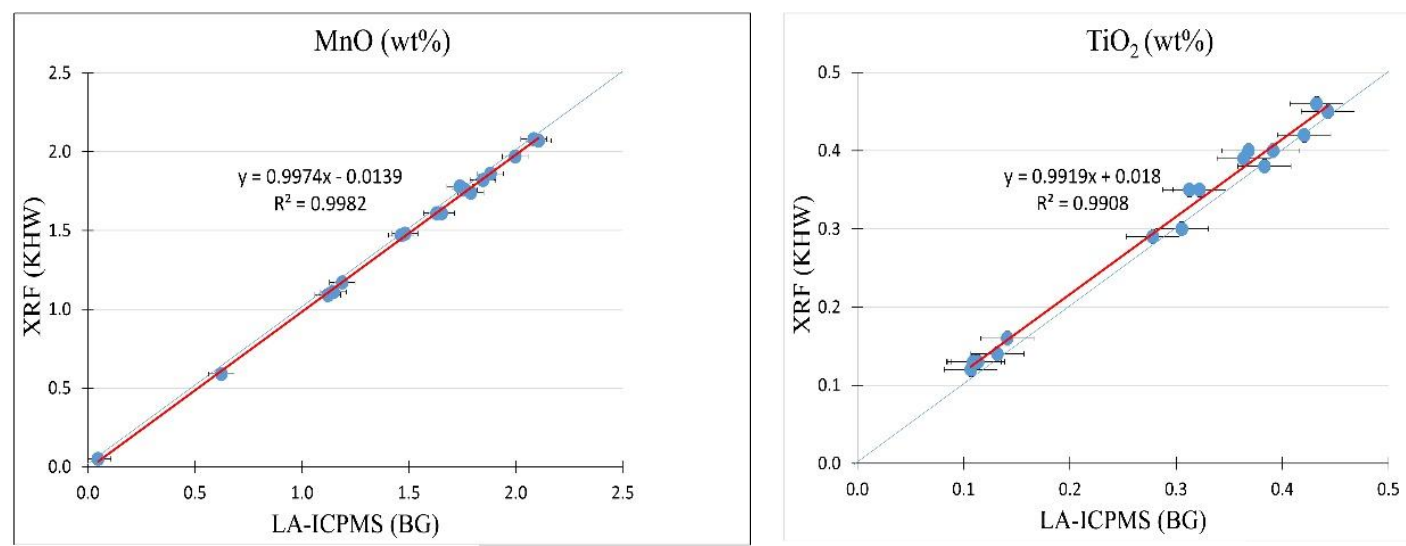

Fig. 2a, b: Scatterplots showing the remarkably close correspondence of analytical results for $\mathrm{MnO}_{\mathrm{and}} \mathrm{TiO}_{2}$ between the WD-XRF analyses done in 1997 and the results by LA-ICPMS on the exact same samples, done in 2015. Horizontal error bars are for 2 standard deviations based on multiple Corning $A$ and $B$ analyses; vertical error bars, based on pers. comm. A. Kronz, are smaller than the symbols. A similarly good correspondence, although not always with the same high $R^{2}$ value, was found for zirconium $\left(R^{2}=0.98\right)$, strontium (0.98), barium (0.97), magnesium (0.90), vanadium (0.89), and potassium (0.67). WD-XRF data from WedepohI \& Hartmann (2000); LA-ICPMS data B. Gratuze, IRAMAT (Orleans).

Systematic discrepancies were found for alumina, where the new data is routinely about 0.1 to 0.2 wt\% higher than the earlier data, and for iron oxide, where the new data is systematically c 0.4 wt\% lower (Fig. 3a, b). But even here, a close correspondence between the two datasets was seen, giving us the confidence to compare the previously published WDS-XRF data with our own LA-ICPMS data, as well as similar newly-analysed data.
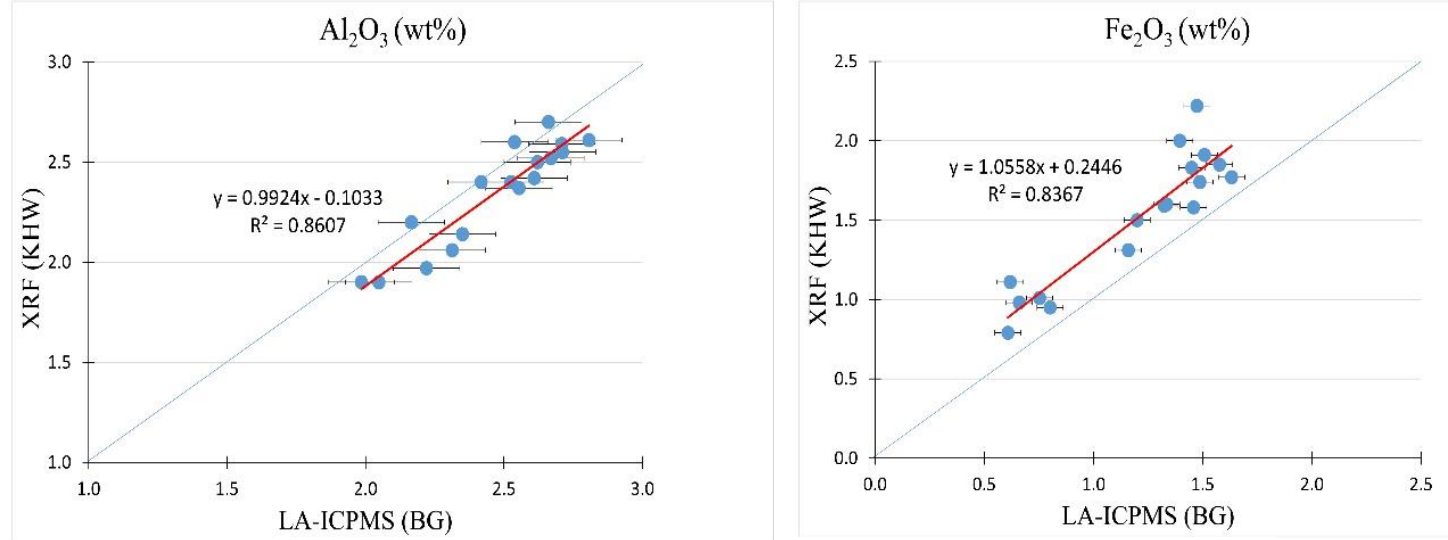

Fig. 3a, b: Scatterplots showing a good correspondence of analytical results for $\mathrm{Al}_{2} \mathrm{O}_{3}$ and $\mathrm{Fe}_{2} \mathrm{O}_{3}$ between the WD-XRF analyses done in 1997 and the results by LA-ICPMS on the exact same samples, done in 2015, but with a systematic offset of the two datasets. Horizontal error bars are for 2 standard deviations based on multiple Corning $A$ and $B$ analyses; vertical error bars, based on pers. comm. A. Kronz, are smaller than the symbols. Similar offsets were found for chromium (about $8 \mu \mathrm{g} / \mathrm{g}$ lower in LA-ICPMS), phosphorus (about 0.01 wt\% lower), and lead (about $35 \mu \mathrm{g} / \mathrm{g}$ lower). WD-XRF data from Wedepohl \& Hartmann (2000); LA-ICPMS data B. Gratuze, IRAMAT (Orleans).

Only for very few elements did we see a significant mismatch between the two datasets, namely for soda and the three transition metals zinc, cobalt and nickel which are present at concentrations near or below the detection limit of the XRF instrument used by Wedepohl and co-workers (pers. comm. A. Kronz). Here, a direct comparison and integration of the datasets will be of limited value. We did not explore whether the discrepancies for soda are due to inherent heterogeneity within the glass, 
given that the analysed volume of glass by LA-ICPMS is vastly smaller than the analysed quantity of glass analysed by WDS-XRF, or whether this is driven by analytical problems with either of the instruments.

\subsection{Grouping the Hambach Forest glass compositions}

We are confident that the re-analysed samples are representative of the overall assemblage of glasses analysed by Wedepohl and Hartmann (2000), and that any future use of his data can be reasonably done, allowing for appropriate corrections for those compounds were a systematic shift has been observed. For the forthcoming discussion, however, we restrict ourselves to the new dataset reported here, to ensure complete internal consistency, as well as close consistency with the wider recent literature, much of which is based on LA-ICPMS analyses.

Our dataset of 56 analysed glass fragments, with a total of 62 individual analyses, conforms to the expected broad compositional pattern of mineral natron-based soda-lime-silica glass, with less than $1 \mathrm{wt} \%$ each of potash and magnesia, and between 15 to $20 \mathrm{wt} \%$ soda (Table 4 ).

Table 4: LA-ICPMS analyses of glass samples from the Hambach Forest, sorted by artefact type (Finished objects; Working waste; and Glass inside melting pots); each section is further sorted by compositional group. Data on two intentionally coloured objects (marked in blue), two outliers (marked in red) and 14 contaminated glass samples is not further discussed in the text below, but is provided for completeness and comparison with other such contaminated glass from elsewhere. Fields highlighted in yellow indicate recycling contamination; fields in brown indicate ceramic or contamination from ceramic material of the melting pots.

The data can be broken down into two compositional groups based on their content in zirconium and titania (Fig. 4a), with a few outliers defined by high lime and partially also high alumina values (Fig. 4b). Significantly, each of the two groups contains samples of finished vessels, of working waste, and of glass retrieved from within crucibles. Thus, it is likely that the glass furnaces are indeed directly linked to the production of many of the glass artefacts excavated in the wider region.
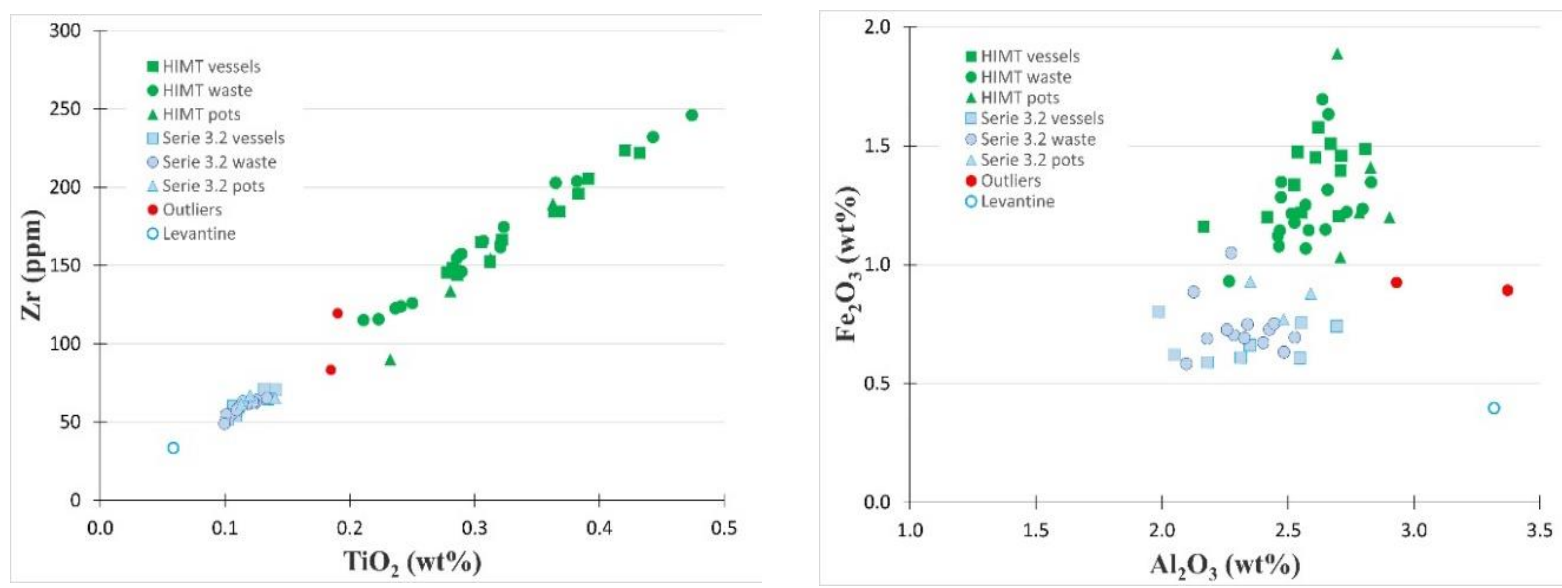

Fig. 4a, b: Scatterplots showing a very tight correlation between zirconium and titanium oxide in the analysed glass samples, falling into two separate groups (left), and a similar clear separation based on iron oxide and alumina (right). LA-ICPMS data B. Gratuze, IRAMAT (Orleans). 


\subsection{Transition metals and colorants}

Over the last 20 years it has been increasingly recognized that the presence of typical colorant elements such as copper, cobalt, tin, antimony and lead in concentrations above their normal geological background levels is indicative of the inclusion of recycled glass cullet in the charge used to produce the analysed vessels (Jackson 1997; Brems \& Degryse 2014). This is understood to be due to the presence, in small quantities, of coloured glass among the cullet, either as trails and dots on decorated glass vessels, or as tesserae. In a previous publication we have defined threshold levels for several colorant and transition metals in HIMT (Rehren \& Brüggler 2015: 174) which we apply here, too. Using this criterion, we see that about $60 \%$ of all analysed HIMT glasses have trace element concentrations consistent with recycling of coloured glass, as well as about half of the analysed série 3.2 glass. There is an interesting tendency among the glasses with recycling indicators that HIMT glass has a significantly higher copper enrichment, while recycled série 3.2 glass is more likely to be richer in antimony (Fig. 5a, b).
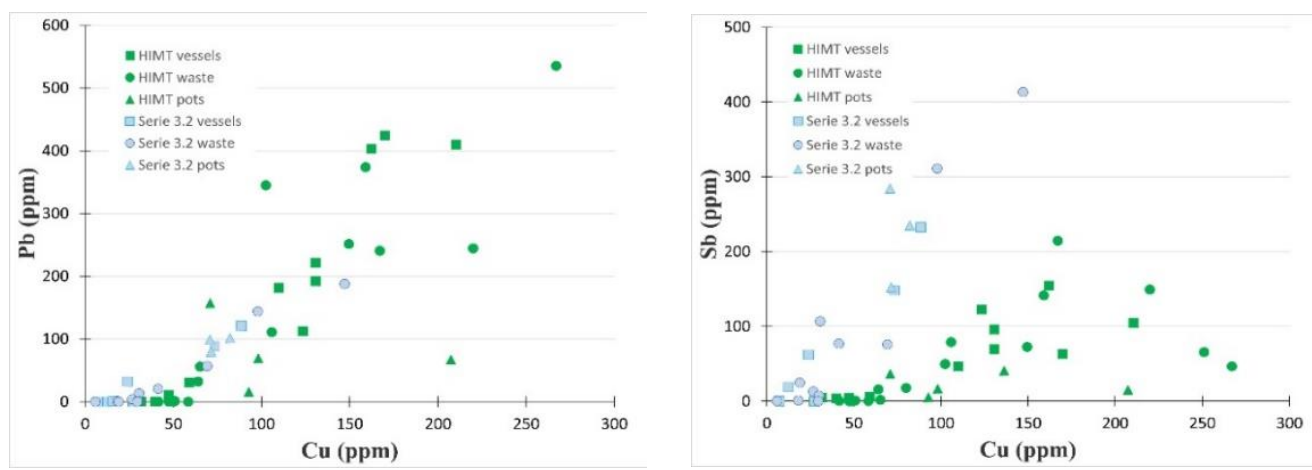

Fig. 5a, b: Scatterplots showing a strong correlation between increased copper and lead content in about half of the analysed glass samples (left), while the série 3.2 glass has a clear tendency to higher antimony contamination (right). LA-ICPMS data B. Gratuze, IRAMAT (Orleans).

\subsection{Comparison of Hambach Forest glass with Late Antique glass compositions}

The last decades have seen an explosion in the number of analyses of Roman and Late Antique glass fragments, resulting in the identification of several major compositional groups (e.g. Freestone et al. 2000, 2002; Foy et al. 2003) and providing a new basis on which to evaluate the observed compositional characteristics of the Hambach Forest glass. The majority of these samples was shown above to have more than c $0.2 \mathrm{wt} \%$ titania and more than $100 \mathrm{ppm}$ zirconium (see Fig. $5 \mathrm{a}$, above); they all have more than $2.5 \mathrm{wt} \%$ combined iron oxide and manganese oxide (Fig. 6), as well as just under $1 \mathrm{wt} \%$ magnesia. Together with the characteristically tight spread of lime and alumina values they fully match the well-known compositional group of High Iron, Manganese and Titania (HIMT) glass first described by Mirti et al. (1993: Group E) and then defined by Freestone (1994) on $4^{\text {th }}$ century AD glass finds from Carthage. ${ }^{2}$ As can be seen from the most recent reviews and compilations of HIMT glass by Nenna (2014), Gliozzo et al. (2017) and Freestone et al. (2018), the iron- and titanium-rich Hambach Forest glasses match in all parameters this major $4^{\text {th }}$ century AD compositional group.

\footnotetext{
${ }^{2}$ More recently, varieties of the abbreviation HIMT have been introduced into the literature which show more modest levels of enrichment of the eponymous elements, such as HIMT 2 (Foster \& Jackson 2009), 'weak HIMT' (Rosenow \& Rehren 2014), and HLIMT (Ceglia et al. 2015), and which in our view are more likely related to Foy et al. (2003) série 3.2 than to HIMT. Here, we follow the concept of the original HIMT sensu stricto (Mirti et al. 1993 Group E; Freestone 1994; groupe 1 (Foy et al. 2003) and HIMT 1 in Foster \& Jackson (2009).
} 


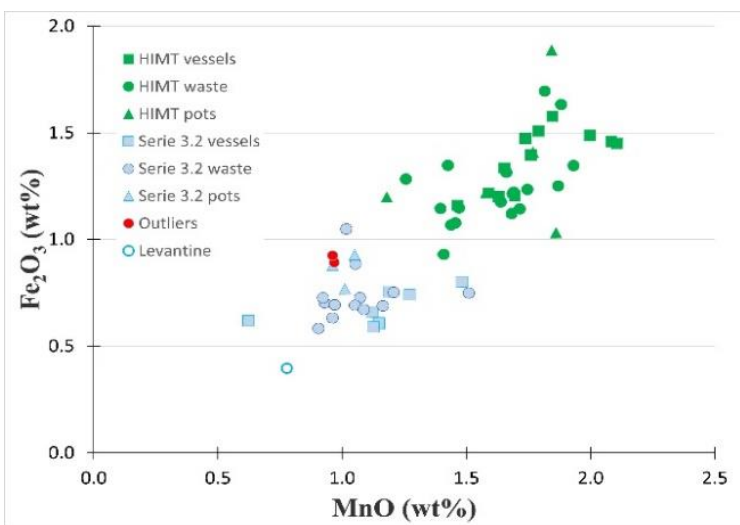

Fig. 6: Scatterplots showing the separation in two groups by their manganese and iron oxide content. LA-ICPMS data B. Gratuze, IRAMAT (Orleans).

A similarly close match across the range of characteristic compositions is found for the minority group of Hambach Forest glass, characterised by somewhat lower zirconium and titania concentrations; these match the composition first defined by Foy et al. (2003) as série 3.2 and more recently identified across wide parts of the Late Antique world, from Britain to Italy, Serbia and Bulgaria (see Cholakova \& Rehren 2018 for a fuller discussion of this compositional group, particularly Table 3.2, and references therein) (Fig. 7). In most of the published contexts, this compositional group is characteristic of glass from the $5^{\text {th }}$ to early $6^{\text {th }}$ century $A D$, although it has been identified from $4^{\text {th }}$ century AD contexts in both Britain and Serbia (Cholakova \& Rehren 2018: 61-2; see also discussion below).

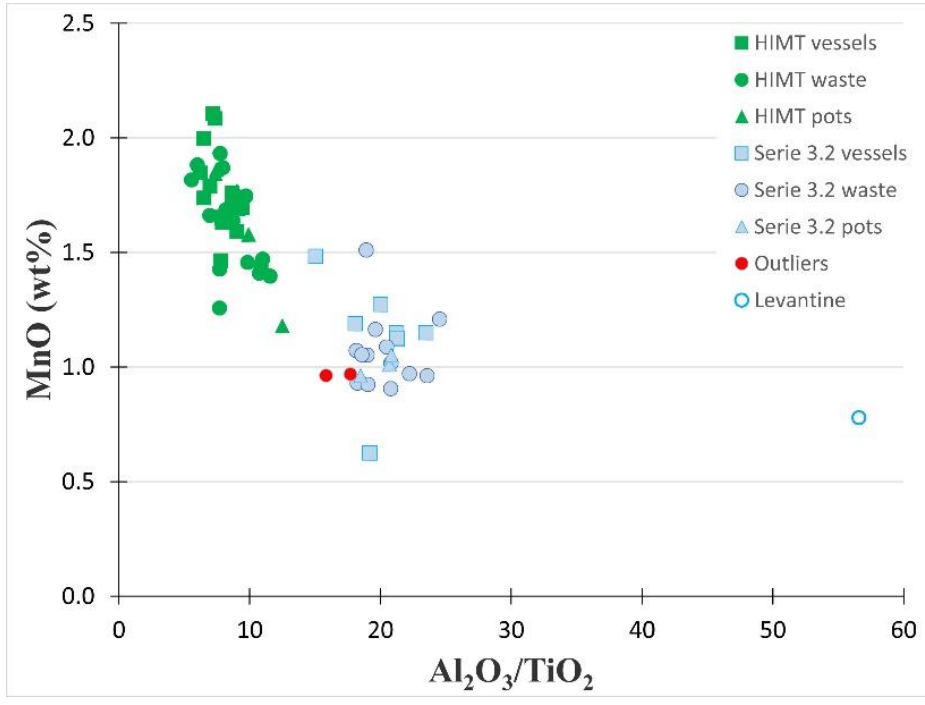

Fig. 7: Scatterplots showing the separation between HIMT and série 3.2 analyses; compare Fig. 3.2 in Cholakova \& Rehren (2018) for a more comprehensive presentation of the relationship between série 3.2 and similar compositional groups recently described in the literature. LA-ICPMS data B. Gratuze, IRAMAT (Orleans).

Only very few of the analysed fragments do not match these two compositional groups. Two of them can be interpreted as resulting from mixing the two main glass compositions, indicated by their intermediate concentrations of titania and other oxides (HaFo 500.4), or affected by contamination during working, as shown by elevated levels of alumina, phosphate and other oxides (HaFo 75.7); these are indicated in the graphs above as outliers. B. Gratuze (pers. comm. June 2018) suggested 
they could belong to a wider group of glasses similar to groupe 2 in Foy et al. (2003). One sample, HaFo 127.2, matches the low-iron and -titanium composition typical of Levantine glass as defined by Freestone et al. $(2000,2002)$.

\subsection{Glass composition and sample types}

We differentiate between samples taken from finished vessels, typically retrieved from graves (samples HA 132.1-8, 132.11-13, HA 382.1-2, 382.7-9; some of the finished vessels stem from other contexts, such as HA 500.1 from the infill of a well and HA 111.8 from the infill of a furnace; the vessel fragments HA75.1, 75.4 and HA 111.9 are not contextualised (Table 2), working waste such as raw glass chunks, glass trails and moils, and the residual glass adhering to crucibles. Thus, we were distinguishing between glass objects which could have been manufactured anywhere, working waste which could either be indicative of local working (moils, trails) or a collection of raw material from elsewhere for local remelting (including moils: see Shepherd 2015: 41), and crucible glass which most certainly had been worked locally. We note that both compositional groups (HIMT and série 3.2) are represented across all three sample types, consistent with a scenario of local glass working producing glass vessels for the local market, using (but not mixing!) both compositions.

There is one exception to this consistency. Five of the 12 HIMT vessel samples analysed by LA-ICPMS show an unusually high content of barium, exceeding $0.1 \mathrm{wt} \%$ and reaching nearly half a percent by weight. This is neither specific to the glass from the Hambach Forest nor a result of local heterogeneity within the analysed samples, as several of these were also analysed by Wedepohl and Hartmann who found the same results (Fig. 8a, b), despite their much larger sample mass. Similarly, Gliozzo et al. (2017: SG10) and Foster and Jackson (2009) report several high-barium samples among their HIMT glasses from Italy and Britain, respectively, reaching even higher levels of up to $0.7 \mathrm{wt} \%$ Ba. Freestone et al. (2018: 173) note that such high barium contents are common in HIMT glass more generally, not only among those from the Hambach Forest. It is noteworthy that none of the analysed working waste or crucible glass fragments belong to this particular composition, but nearly half of the analysed vessels, potentially indicating that they were imported rather than locally made.
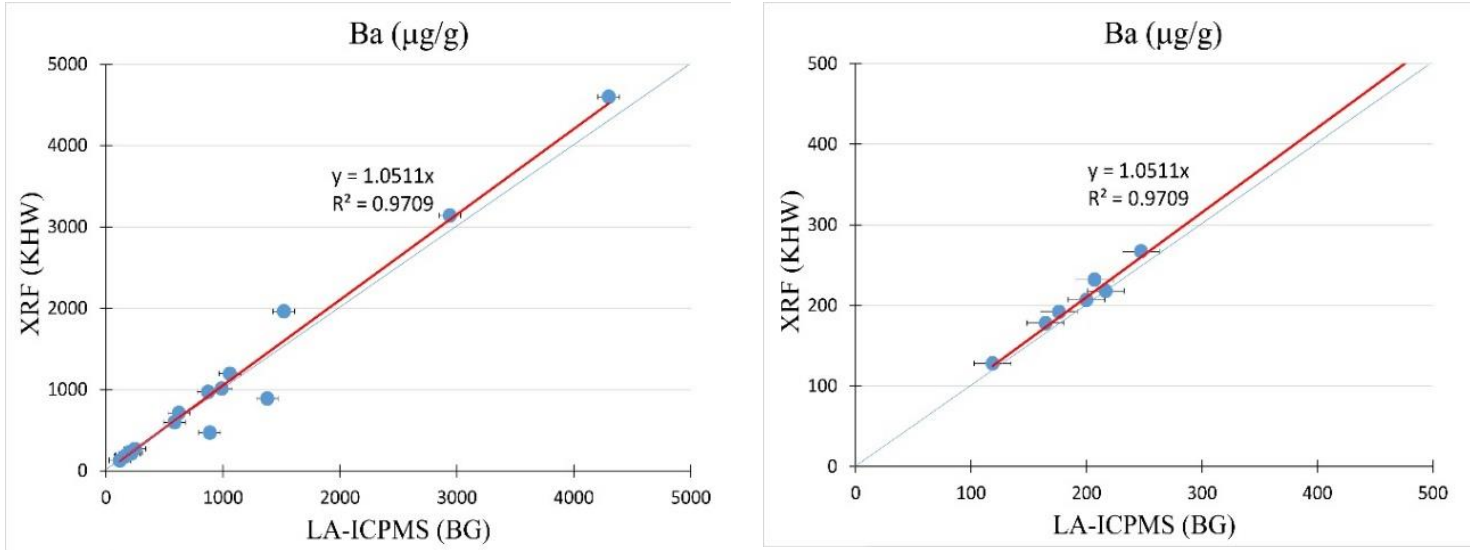

Fig. 8a, b: Scatterplots showing close correspondence of analytical results for barium between the WD-XRF analyses done in 1997 and the results by LA-ICPMS on the exact same samples, done in 2015. Horizontal error bars are for 2 standard deviation based on multiple Corning $A$ and $B$ analyses; vertical error bars, based on pers. comm. A. Kronz, are smaller than the symbols. The correspondence includes samples with very high barium concentrations, typical of some HIMT glasses. WD-XRF data from Wedepohl \& Hartmann (2000); LAICPMS data B. Gratuze, IRAMAT (Orleans). 


\subsection{Chronology of glass compositions at Hambach Forest}

The nature of the archaeology at the Hambach Forest limits our ability to closely date most of the sites; for about half of our samples (29 out of 56), only the very broad overall date range from the early $4^{\text {th }}$ to the mid- $5^{\text {th }}$ century AD can be given (see Tables 1 and 2, above). Where a closer date range can be assigned, the distribution of the two main glass compositions paints an interesting trend (Table 2, above). Of the more closely dated samples, 15 date to the early to mid- $4^{\text {th }}$ century $A D, 1$ is dated mid- $4^{\text {th }}$ to early $5^{\text {th }} c A D$, and 11 are dated to the $2^{\text {nd }}$ half of the $4^{\text {th }}$ to the early $5^{\text {th }} c$ AD. Thirteen of the early finds have série 3.2 composition, 1 is HIMT and 1 an outlier. In contrast, 9 of the late finds have HIMT composition, and only 1 each is série 3.2 glass and outlier composition, respectively. Even allowing for a considerable margin of error in the dating of the individual finds we note a very strong tendency of the glass composition série 3.2 to dominate the finds from the early to mid- $4^{\text {th }}$ century AD, and for the later finds to be overwhelmingly of HIMT composition.

\section{Discussion}

Furnaces for glass working are widely known across the Roman and Late Antique Empire (e.g. Price \& Cool 1991; Foy 2000; Fischer 2009; Antonaras 2014; Da Cruz \& Sanchez De Prado 2015; Lepri \& Sagui 2017), and well understood in their operation to re-melt existing glass, either freshly imported chunks and / or recycled cullet. This is also the case for most of the furnaces excavated at the Hambach Forest (Gaitzsch et al. 2000), linking them to the secondary production of glass. The arguments for a primary glass production in some of the Hambach Forest furnaces have been summarized by Wedepohl et al. (2003: 59; cf. also Brüggler 2009, 86-90). These include the evidence for a small - uncertain - tank furnace (HA 111), the presence of two specific glass compositions among the finds from the furnaces, namely one relatively low in iron oxide and one with much higher and seemingly unique iron oxide content, the broad match of a wide spread in concentrations of trace elements such as zirconium, barium and lead among the overall glass assemblage from the Hambach Forest furnaces with a number of sand samples from the local river Rur, and finally the similarity of lead isotope ratios in some of the glasses with those from the neighbouring Roman lead mining regions in the Eifel. Thus, central to the argument for primary production of glass at the Hambach Forest is the supposedly unique chemical signature of the Hambach Forest glass finds analysed in the $1990 \mathrm{~s}$, compared to nearly 600 published analyses of $1^{\text {st }}$ to $5^{\text {th }} \mathrm{c} A D$ glass from across Europe (Wedepohl \& Hartmann 2000: 143, table 11). In this comparison, the Hambach Forest glasses stand out by their higher content in titanium, iron, manganese, magnesium, zirconium and barium, and somewhat lower calcium oxide concentrations around $6 \mathrm{wt} \%$. The high iron oxide content in particular, reaching 1.4 to $2.2 \mathrm{wt} \% \mathrm{Fe}_{2} \mathrm{O}_{3}$, compared to an average of only 0.7 wt $\% \mathrm{Fe}_{2} \mathrm{O}_{3}$ in 700 Roman glasses from Europe and Israel, was singled out again by Wedepohl et al. (2003: 57) as indicative of a local glass production.

\subsection{A unique glass composition at the Hambach Forest?}

Our work presented here firstly confirms the very high precision for most elements analysed for by Wedepohl and Hartmann more than 20 years ago. Of significance for our discussion here is the regular over-estimation of iron oxide in the published data from Hambach Forest by about $0.4 \mathrm{wt} \%$ above the new LA-ICPMS data, and a similar under-estimation of alumina by c 0.1 to $0.2 \mathrm{wt} \%$ (see above, Fig. 3); both oxides are relevant for the discussion of HIMT glass (e.g. Freestone et al. 2005; Gliozzo et al. 2017: Fig. 4; Freestone et al. 2018: Figs. 8.1 and 8.2). However, this overestimation of 
iron oxide is insufficient to explain the much higher iron oxide content in the Hambach Forest glasses compared to the other 'Roman' glasses compiled by Wedepohl et al. (2003). Finally, the new work does provide much improved data for transition metals including copper, an important trace element in Late Antique glass when discussing recycling, and more reliable data for several other elements present in the glass at concentrations close to or below the detection limit of WDS-XRF.

With the benefit of this new data and 20 years of accumulated Roman and Late Antique glass research we are now in a position to re-evaluate the compositional data from the Hambach Forest. As we have shown above, the notion of a unique compositional pattern restricted to the regional glass from the Hambach Forest cannot be maintained any longer. The two different glass compositions, separated based on their iron and manganese contents as already noted by Wedepohl et al. (2003: Fig. 5), can now be shown to match very closely the two major Late Antique compositional glass groups known as HIMT and série 3.2, respectively, for the high-iron and mediumiron compositions. It is significant for our discussion that these two major glass compositions are documented across a very wide part of the Late Antique empire, from northern Britain to France, Italy, northern Africa and the Balkans, where they dominate glass compositions during the $4^{\text {th }}$ and $5^{\text {th }}$ centuries $A D$, exactly the period of operation at the Hambach Forest glass furnaces.

In contrast, the comparative data used by Wedepohl and co-workers to assess their Hambach Forest glass analyses were dominated by earlier glass compositions, from the $1^{\text {st }}$ to $3^{\text {rd }} / 4^{\text {th }}$ century AD (see Wedepohl \& Hartmann 2000: 143). These earlier glasses are known to have systematically lower concentrations of iron and related oxides than the later ones (cf. Freestone et al. 2018 for a discussion of this shift in composition). Thus, the difference observed by Wedepohl and co-workers is not one between imported Roman and locally produced Hambach Forest glass, but one of earlier vs. later glass compositions, tracing a trend to more iron-rich compositions seen across almost the entire Roman and Late Antique world. Significantly, the high-barium samples among the HIMT composition from the Hambach Forest are restricted to finished vessels; none of the working waste or crucible glass shows this particular feature. We cannot therefore see this as a characteristic of the locally-worked glass, even though the sands of the local river Rur show similarly variable to high barium contents as the HIMT glass (Wedepohl \& Hartmann 2000: 135). While exact production locales for both compositional groups are still unknown it is generally assumed that they were made in Egypt (HIMT) and the Levant more generally (série 3.2), where suitable sand sources are known to have been exploited for glass making at a massive scale, using the mineral natron from Egypt as the common fluxing material (Foy et al. 2003; Nenna 2014; Freestone 2018).

The close compositional correspondence of the glass from the Hambach Forest with glass found elsewhere in the Late Antique world does not a priori exclude the possibility that this glass was locally made in the region, particularly given that there are no archaeologically documented production sites for either of these glass compositions. However, the scale of operation documented in the Hambach Forest, while large when seen in relation to the typical Roman glass furnaces elsewhere (e.g. Bayley 1991; Price \& Cool 1991; Fischer 2009; Da Cruz \& Sanchez De Prado 2015; Shepherd 2015), is far below the scale documented from Byzantine glassmaking sites in Israel and Lebanon (e.g. Gorin-Rosen 2000; Aldsworth et al. 2002; Tal et al. 2004; Nenna 2015), and not sufficient to plausibly explain the production of glass found all over the Empire. Similarly, we consider it very unlikely that a relatively small amount of glass was produced at the Hambach Forest from imported natron and local Rur sand, sufficient for the local vessel production, and by coincidence matching across all analysed elements exactly the glass composition of vessels found elsewhere during this time, from York to southern France, northern Egypt and eastern Bulgaria. 
Another argument brought forward in favour of a local primary glass production is the similarity of the lead isotope signature from several analysed glass fragments, to the local Eifel lead mines for which Roman exploitation is recorded. We have shown above (see Fig. 6a) that the amount of lead in freshly-made glass is very low, well below $50 \mathrm{ppm}$, compared to that found in those glass fragments with elevated lead content, reaching $800 \mathrm{ppm}$. We argue that this elevated lead content, which goes hand in hand with elevated copper, tin and antimony, is due to the incorporation of copper-blue and other coloured or decolourised glass in the batch, as part of common recycling practice (see Freestone 2015 for a recent review of glass recycling, and the literature therein, particularly the early work by C.M. Jackson; see also Rehren \& Brüggler 2015: 174-176). Thus, the lead isotope signature in those glasses reflects most likely the geological origin of the lead added as part of coloured cullet during glass recycling; this is indicated by the close correlation of lead, copper, tin and antimony (see Figs. 5a, b). It is reasonable to assume that the local glassworkers made their own copper-coloured glass using locally available metal scrap which would have added a local lead component to the charge, which during recycling would then spread across the wider charge of colourless glass. A base-fragment of a crucible with a partly-molten copper object found in Asperden might point in that direction (Brüggler 2014, 95 fig. 18). The lead content of fresh raw glass is so low compared to the lead added through recycling (see Fig. 5a) that the lead isotope signatures of the raw glass will be fully obscured by the colorant signature. It is also noteworthy that Wedepohl et al. (2003) found that the cobalt-blue glass does not match the local lead isotope signature; this is logical since the cobalt coloured glass would have come from a specialist producer elsewhere.

While we have shown a very close consistency between the two main glass compositions from the Hambach Forest and the compositional groups of the $4^{\text {th }}$ and $5^{\text {th }}$ century AD found across the wider Late Antique world, we also note an apparent discrepancy in the relative dating of the dominance of the two compositions. Elsewhere, HIMT is seen as a typical $4^{\text {th }}$ century composition (Nenna 2018, and literature therein), while série 3.2 is most often associated with $5^{\text {th }}$ century glass assemblages (Foy et al. 2003; see also the summary in Cholakova \& Rehren 2018). At the Hambach Forest the serie 3.2 composition dominates the earlier glass finds, from the first half of the $4^{\text {th }}$ century AD, while samples dated to the second half of the $4^{\text {th }}$ and early $5^{\text {th }}$ century AD are predominantly made of HIMT glass. Foster \& Jackson (2009) report data on a large number of naturally-coloured RomanoBritish glass finds mostly from the $4^{\text {th }}$ century AD. They, too, find a separation of their data into two compositional groups separated by their content in iron and manganese oxide, titania, zircon etc. They link both to the HIMT composition, labelling the group with higher concentrations in these elements as HIMT 1, and the other as HIMT 2, with only about half the concentrations of these oxides. We note that their HIMT 2 compositional group has many characteristics in common with série 3.2 as defined by Foy et al. (2003). Interestingly, they also note that none of the samples confidently dated to the early to mid- $4^{\text {th }}$ century AD are made from HIMT 1 , while 7 samples of this date have the HIMT 2 (potentially série 3.2 ) composition. Among the mid- to late $4^{\text {th }}$ century AD samples, HIMT 1 outweighs HIMT 2 composition 3 to 1 . Thus, the assemblages from Britain and the Hambach Forest seem to share the same chronological shift, with the emergence of série 3.2 glass predating the rise of HIMT glass by half a century or so, in contrast to the finds analysed by Foy et al. (2003) which were excavated at several sites in southern France, and where série 3.2 glass postdates HIMT.

\section{Conclusion}

The chemical analyses published by Wedepohl and Hartmann in 2000 are of very high quality and can for most elements be used with minimal adjustment alongside more recent LA-ICPMS data. 
However, the massive increase of published analyses of Late Antique glass over the past two decades enables now a re-interpretation of the data from the Hambach Forest and the Rhineland more generally within the overall context of mineral natron glass production and consumption of the first millennium AD. It is now clear that there were several large-scale primary glass producers which supplied the entire Empire with glass, and that several of these producers only operated for a relatively short period of one or two centuries. Thus, a comparison of the Late Antique glass from the Hambach Forest only with predominantly earlier Roman glass will inevitably lead to a mis-match and seemingly unique composition of the Hambach glass. Using data of $4^{\text {th }}$ and $5^{\text {th }}$ century glass found elsewhere we recognize the glass compositions from the Hambach Forest as closely matching the two major compositional groups dominating glass vessel production during these two centuries from the Balkans through the northern provinces to the western Mediterranean and northern Africa. We therefore conclude that there is no basis anymore to see the glass compositions from the Hambach Forest as unique among analysed Roman and Late Antique glasses, and to argue for a local primary glass production in the Hambach Forest, or elsewhere in the Rhineland. The contemporary major glass compositions known as HIMT and série 3.2, respectively, match very closely the two glass compositions dominating among the Hambach Forest assemblage, including the full suite of analysed trace elements. The consistency of composition of the working waste and crucible glass from the furnaces in the Hambach Forest with the glass finds from surrounding graves and settlements demonstrates that the undoubtedly important local glass industry was entirely focussed on the (secondary) production of glass vessels. For this, the different glass furnaces had access variously to fresh raw glass imported as chunks from the eastern Mediterranean, but also relied on the re-melting of locally collected cullet. Thus, the range of glass compositions documented from the wider region, spanning the period of Roman occupation through to the Frankish and Carolingian periods reflects the ebb and flow of commerce between the Rhineland and the eastern Mediterranean, but also the shifting activities of the primary producers in the East.

\section{Acknowledgements}

The authors would like to thank Udo Geilenbrügge and Petra Tutlies (LVR-State Service for the Archaeological Heritage in the Rhineland) and Susanne Willer (LVR-LandesMuseum Bonn) for agreeing to the renewed sampling; Wolfgang Gaitzsch, Düren, Jennifer Komp and Christiane Dirsch (both LVR-LandesMuseum Bonn) helped with the extraction of the samples as well as Constanze Höpken, Ottweiler. We are grateful to Bernard Gratuze for providing the analyses and helpful comments on the data, and to Andreas Kronz for information concerning the original XRF analyses done in Göttingen. This publication was made possible by NPRP grant 7- 776- 6- 024 from the Qatar National Research Fund (a member of Qatar Foundation). The statements made herein are solely the responsibility of the authors. We acknowledge the detailed comments by two reviewers which helped to strengthen the paper; any remaining shortcomings are ours.

\section{References}

Adlington, L. W. 2017. The Corning archaeological reference glasses: New values for "Old" compositions. Papers from the Institute of Archaeology, 27(1): Art. 2, pp. 1-8, DOI: https://doi.org/10.5334/pia-515

Aldsworth, F., Haggarty, G., Jennings, S. \& Whitehouse, D. 2002. Medieval glass-making at Tyre, Lebanon, Journal of Glass Studies 44, 49-66. 
Antonaras, A. 2014. An early Christian glass workshop at 45, Vasileos Irakleiou Street in the centre of Thessaloniki. In: D. Keller, J. Price \& C.M. Jackson (eds), Neighbours and Successors of Rome Traditions of glass production and use in Europe and the Middle East in the Later $1^{\text {st }}$ millennium $A D$, 95-113. Oxbow Books, Oxford.

Băeştean, G. \& Höpken, C. 2009. Ein römischer Wannenofen zum Glasschmelzen in Sarmizegetusa (Rumänien). Journal of Glass Studies 51, 219-223.

Brems, D. \& Degryse, P. 2014. Trace element analysis in provenancing Roman glass-making. Archaeometry 56, Suppl. 1, 116-136.

Brems, D., Degryse, P., Hasendoncks, F., Gimeno, D., Silvestri, A., Vassilieva, E., Luypaers, St. \& Honings, J. 2012. Western Mediterranean sand deposits as a raw material for Roman glass production. Journal of Archaeological Science 39, 2897-2907.

Brüggler, M. 2009. Villa rustica, Glashütte und Gräberfeld. Die kaiserzeitliche und spätantike Siedlungsstelle HA 132 im Hambacher Forst. Rheinische Ausgrabungen 63, Mainz.

Brüggler, M. 2014. Burgus und Glaswerkstatt der Spätantike bei Goch-Asperden. Bonner Jahrb. 214, 71-134.

Brüggler, M. forthcoming. Glass working in Germania secunda. In: F. Klimscha, H.-J. Karlsen, S. Hansen \& J. Renn (eds.), Vom Künstlichen Stein zum Klaren Massenprodukt. Glasnutzung und Glasproduktion in Bronzezeit und Antike. From Artificial Stone to Mass-Produced Translucence. Use and Production of Glass in Bronze Age and Antiquity. Berlin Studies of the Ancient World 67 (Berlin 2020)

Brüggler, M. \& Daszkiewic, M. 2004, Spätantike Glasherstellung im Hambacher Forst. Ergebnisse der Laboranalysen vom Fundplatz HA 132. Kölner Jahrbuch 37, 805-818.

Brüggler, M. \& Rehren, Th. 2014. Die spätantiken Glasschalen vom Typus Helle und ihre chemische Zusammensetzung. Bonner Jahrb. 214, 163-180.

Ceglia, A., Cosyns, P., Nys, K., Terryn, H., Thienpont, H. \& Meulebroeck, W. 2015. Late antique glass distribution and consumption in Cyprus: a chemical study. Journal of Archaeological Science 61, 213-222.

Cholakova, A. \& Rehren, Th. 2018. A Late Antique manganese-decolourised glass composition: Interpreting patterns and mechanisms of distribution. In: D. Rosenow, M. Phelps, A. Meek and I.C. Freestone (eds), Things that Travelled - Mediterranean Glass in the First Millennium CE. UCL Press, 46-71.

Cholakova, A., Rehren, Th. \& Freestone, I.C. 2016: Compositional identification of 6th c. AD glass from the Lower Danube. Journal of Archaeological Science: Reports 7, 625-632.

Cool, H., Jackson, C.M. \& Monaghan, J. 1999. Glass-making and the Sixth Legion at York. Britannia $30,147-162$.

Da Cruz, M. \& Sanchez de Prado, M.D. 2015. Glass working sites in Hispania: what we know. In: I. Lazar (ed.), Annales du 19e Congrès de AIHV, 178-187.

Degryse, P. (ed) 2014. Glass Making in the Greco-Roman World. Leuven University Press.

Degryse, P. 2017. Chemical signature and scale of production of primary glass factories around the Mediterranean in the first millennium AD. In: S. Wolf \& A. de Pury-Gysel (eds), Annales du 20e Congrès de l'Association Internatinale pour l'Histoire du Verre, 175-180, Romont.

Fischer, A. 2009. Vorsicht Glas! Die römischen Glasmanufakturen von Kaiseraugst. Forschungen in Augst 37, Augusta Raurica. 
Follmann-Schulz, A.-B. 2015. The Hambach glass production in the Late Roman period. In: J. Bayley, I.C. Freestone and C.M. Jackson (eds), Glass of the Roman World, 23-32. Oxbow Books, Oxford.

Foster, H. \& Jackson, C.M. 2009. The composition of 'naturally coloured' late Roman vessel glass from Britain and the implications for models of glass production and supply. Journal of Archaeological Science 36, 189-204.

Foy, D. 2000. Technologie, géographie, économie. Les ateliers de verriers primaries et secondaires en occident esquisse d'une évolution de l'Antiquité au Moyen Âge. In: La Route du Verre, Ateliers primaires et secondaires du second millénaire av. J.-C. au Moyen Âge, 147-170. Lyon.

Foy, D., Picon, M., Vichy, M., \& Thirion-Merle, V. 2003. Caractérisation des verres de la fin de l'Antiquité en Méditerranée occidentale: l'émergence de nouveaux courants commerciaux. In: D. Foy \& M.-D. Nenna (eds), Échanges et commerce du verre dans le monde antique, 41-85. Instrumentum Monographies 24, Éditions Monique Mergoil, Montagnac.

Freestone, I.C., 1994: Chemical analysis of 'raw' glass fragments. In: H.R. Hurst (Ed.), Excavations at Carthage, Vol. II, 1, The Circular Harbour, North Side. Oxford University Press, 290

Freestone, I.C. 2015. The recycling and reuse of Roman glass: analytical approaches. Journal of Glass Studies 57, 1-12.

Freestone, I.C., Gorin-Rosen, Y. \& Hughes, M. 2000. Primary glass from Israel and the production of glass in Late Antiquity and the Early Islamic Period. In: M.-D. Nenna (ed.), La Route du verre. Ateliers primaires et secondaires du second millénaire av. J.-C. au Moyen Âge, 65-83.

Freestone, I.C., Ponting, M. \& Hughes, M. 2002. The origins of Byzantine glass from Maroni Petrera, Cyprus. Archaeometry 44, 257-272.

Freestone, I.C., Wolf, S. \& Thirlwall, M., 2005. The production of HIMT glass: elemental and isotopic evidence. Annales AIHV 16: 153-157.

Freestone, I.C., Wolf, S. \& Thirlwall, M., 2009. Isotopic composition of glass from the Levant and the south-eastern Mediterranean Region. In: P. Degryse, J. Henderson \& G. Hodgins (eds) Isotopes in Vitreous Materials, 31-52, Leuven University Press.

Freestone, I.C., Degryse, P., Lankton, J., Gratuze, B. \& Schneider, J. 2018. HIMT, glass composition and commodity branding in the primary glass industry. In: D. Rosenow, M. Phelps, A. Meek and I.C. Freestone (eds), Things that Travelled - Mediterranean Glass in the First Millennium CE, 159180. UCL Press, London.

Gaitzsch, W., Follmann-Schulz, A.B., Wedepohl, K.H., Hartmann, G. \& Tegtmeier, U. 2000. Spätrömische Glashütten im Hambacher Forst - Produktionsort der ECVA-Fasskrüge. Bonner Jahrbücher 200, 81-240.

Gaitzsch, W., Haarich, H., Janssen, J. 2007. Merzenisch, Kreis Düren. Bonner Jahrb. 207, 326.

Gliozzo, E., Braschi, E., Giannetti, F., Langone, A. \& Turchiano, M. 2017. New geochemical and isotopic insights in the Late Antique Apulian glass and the HIMT1 and HIMT2 glass productionsthe glass vessels from San Giusto (Foggia, Italy) and the diagrams for provenance studies. Archaeological and Anthropological Sciences, online.

Gorin-Rosen, Y. 2000. The ancient glass industry in Israel - summary of the finds and new discoveries. In: La Route du Verre, Ateliers primaires et secondaires du second millénaire av. J.-C. au Moyen Âge, 49-63. Lyon.

Gratuze, B. 2013. Glass characterisation using Laser Ablation Inductively Coupled Plasma Mass Spectrometry methods. In: K. Janssens (ed.), Modern Methods for Analysing Archaeological and Historical Glass, 201-234. Wiley. 
Grünewald, M. \& Hartmann, S. 2015, Überlegungen zum Glasrecycling der Antike auf dem Gebiet des heutigen Deutschland. In: P. Henrich, Ch. Miks, J. Obmann and M. Wieland (eds), NON SOLUM ... SED ETIAM. Festschrift für Thomas Fischer zum 65. Geburtstag, Rahden/Westf., 153164.

Hallmann-Preuß, B. 2002/2003: B. Hallmann-Preuß, Die Villa Rustica Hambach 59, eine Grabung im Rheinischen Braunkohlerevier. Saalburg-Jahrb. 52/53, 283-536.

Heege, A. 1997, HA 500. Villa rustica und früh- bis hochmittelalterliche Siedlung Wüstweiler (Gemeinde Niederzier), Kreis Düren. Rheinische Ausgrabungen 41, Köln.

Jackson, C.M., 1997: From Roman to early Medieval glasses - many happy returns or a new birth? In: Annales du 13e Congres de l'A.I.H.V., Pays Bas 1995 (Lochem 1997) 289-302.

Jackson, C.M., Cool, H.E.M., \& Wager, E.C.W. 1998. The manufacture of glass in Roman York. Journal of Glass Studies 40, 55-61.

Jackson, C.M., Joyner, L., Booth, C.A., Day, P.M. \& Wager, E.C.W. 2003. Roman glass-making at Coppergate, York? Analytical evidence for the nature of production. Archaeometry 45, 435-456.

Keily, J. \& Shepherd, J. 2005. Glass working in the upper Walbrook valley. In: F. Seeley \& J. Drummond-Murray (eds), Roman pottery production in the Walbrook valley, MoLAS Monograph 25, 147-155. Museum of London Archaeology Service, London.

Lepri, B. \& Saguì, L. 2017. Mapping glass production in Italy. Looking through the first millennium AD. In: S. Wolf \& A. de Pury-Gysel (eds), Annales du 20e Congrès de l'Association Internatinale pour I'Histoire du Verre, 168-174, Romont.

Mirti, P., Casoli, A. \& Appolonia, L. 1993. Scientific analysis of Roman glass from Augusta Praetoria. Archaeometry 35, 225-240.

Nenna, M.-D. 2006. Verres de l'antiquité gréco-romaine: cinq ans de ublications (2000-2004). Revue Archéologique 2006, 83-166.

Nenna, M.-D. 2014. Egyptian glass abroad: HIMT glass and its markets. In: D. Keller, J. Price \& C.M. Jackson (eds), Neighbours and Successors of Rome - Traditions of glass production and use in Europe and the Middle East in the Later $1^{\text {st }}$ millennium AD, 177-193. Oxbow Books, Oxford.

Nenna, M.-D. 2015. Primary glass workshops in Graeco-Roman Egypt: preliminary report on the excavations of the site of Beni Salama, Wadi Natrun (2003, 2005-9). In: J. Bayley, I.C. Freestone and C.M. Jackson (eds), Glass of the Roman World, 1-22. Oxbow Books, Oxford.

Price, J. 2003. Broken bottles and quartz-sand: glass production in Yorkshire and the North in the Roman period. In: Aspects of Industry in Roman Yorkshire and the North, Oxford: Oxbow Books, 81-93.

Price, J. 2005. Glass-working and glassworkers in cities and towns. In: Roman working lives and urban living, Oxford: Oxbow Books, 167-190.

Price, J. \& Cool, H. 1991. The evidence for the production of glass in Roman Britain. In: D. Foy \& G. Sennequier (eds), Ateliers de verriers de l'Antiquité à la période pré-industrielle (= Actes des 4emes Rencontres de l'AFAV), 23-30. Rouen.

Rehren, Th. \& Brüggler, M. 2015. Composition and production of late antique glass bowls type Helle. Journal of Archaeological Science: Reports 3, 171-180.

Rehren, Th. \& Cholakova, A., 2010, The early Byzantine HIMT glass from Dichin, Northern Bulgaria. Interdisciplinary Studies 22/23, 81-96.

Rehren, Th. \& Kronz, A. 2017. Karl Hans Wedepohl (1925-2016). Journal of Glass Studies 59, 454-457. 
Rehren, Th., Spencer, L. \& Triantafyllidis, P. (2005): The primary production of glass at Hellenistic Rhodes. In: H. Cool, ed, Annales du 16e Congres de l'Association Internationale pour l'Histoire du Verre, Nottingham, 39-43.

Rehren, Th., Connolly, P., Schibille, N. \& Schwarzer, H. 2015: Changes in glass consumption in Pergamon (Turkey) from Hellenistic to late Byzantine and Islamic times. Journal of Archaeological Science 55, 266-279.

Rosenow, D. \& Rehren, Th. 2014: Herding cats - Roman to Late Antique glass groups from Bubastis, northern Egypt. Journal of Archaeological Science 49, 170-184.

Saleh, S.A., George, A.W. \& Helmi, F.M. 1972. Study of glass and glassmaking processes at Wadi elNatrun, Egypt in the Roman period 30 B.C. to 359 A.D. Part 1 Fritting crucibles, their technical features and temperatures employed. Studies in Conservation 17, 143-172.

Shepherd, J. 2015. A gazetteer of glass working sites in Roman London. In: J. Bayley, I.C. Freestone and C.M. Jackson (eds), Glass of the Roman World, 33-43. Oxbow Books, Oxford.

Tal, O., Jackson-Tal, R. \& Freestone, I.C. 2004. New evidence of the production of raw glass at Late Byzantine Apollonia-Arsuf, Israel. Journal of Glass Studies 46, 51-66.

Wagner, G., Brüggler, M. \& Grünewald, M. in print: Spätantike Glasöfen im Hambacher Forst bei Düren. In: B. Birkenhagen, C. Höpken, M. Brüggler (Eds.), Römische Glasöfen - Befunde, Funde und Rekonstruktionen in Synthese/Roman glass furnaces - contexts, finds and reconstructions in synthesis. Conference Borg 2016.

Wagner, G. in preparation: Villa rustica und spätantike Glashütte HA 382 im Hambacher Forst. Dissertationsvorhaben an der Universität zu Köln.

Wedepohl, K.H. 1997. Chemical composition of medieval glass from excavations in West Germany. Glastech. Ber. Glass Sci. Technol. 70, No. 8, 246-255.

Wedepohl, K.H. 2003. Composition of Carolingian glass in Europe. Annales du 16e Congrès de l'AlHV, 203-206.

Wedepohl, K.H. \& Baumann, A. 2000. The use of marine molluscan shells for Roman glass and local raw glass production in the Eifel area (Western Germany). Naturwissenschaften 87, 129-132.

Wedepohl, K.H. \& Hartmann, G. 2000. Die chemische Zusammensetzung der spätkaiserzeitlichen Gläser. In: Gaitzsch, W., Follmann-Schulz, A.B., Wedepohl, K.H., Hartmann, G. \& Tegtmeier, U. 2000. Spätrömische Glashütten im Hambacher Forst - Produktionsort der ECVA-Fasskrüge. Bonner Jahrbücher 200, 131-161.

Wedepohl, K.H., Pirling, R. \& Hartmann, G. 1997. Römische und fränkische Gläser aus dem Gräberfeld Krefeld-Gellep. Bonner Jahrbücher 197, 177-189.

Wedepohl, K.H., Gaitzsch, W. \& Follmann-Schulz, A.B. 2003. Glassmaking and glassworking in six Roman factories in the Hambach Forest. Annales du 15e Congrès de l'AlHV, 56-61.

Wilson, A., Schörle, K \& Rice, C., 2012. Roman ports and Mediterranean Connectivity. In: S. Keay (Ed.) Rome, Portus and the Mediterranean, 367-392. London: British School at Rome. 